Legal Regime and Business's Organizational Choice: A Comparison of France and the United States during the Mid-Nineteenth Century

Draft of Jan 22, 2004

Naomi R. Lamoreaux

Economics and History, UCLA, and NBER

and

Jean-Laurent Rosenthal

Economics, UCLA, and INRA-LEA, Paris

Contact information:

Naomi R. Lamoreaux, Department of Economics, University of California, Los Angeles, CA 90095-1477 Phone: 310-825-0225 Fax: 310-825-9528. Email: lamoreaux@econ.ucla.edu

Jean-Laurent Rosenthal, Department of Economics, University of California, Los Angeles, CA 90095-1477 Phone: 310-825-2490 Fax: 310-825-9528. Email: rosenthal@econ.ucla.edu 


\title{
Legal Regime and Business's Organizational Choice: A Comparison of France and the
}

\author{
United States during the Mid-Nineteenth Century
}

\begin{abstract}
In a recent series of articles, Rafael La Porta, Florencio Lopez-de-Silanes, Andrei Shleifer, and Robert W. Vishny have argued that countries whose legal systems are based on civil law (especially of French origin) have systematically weaker environments for business than those whose legal systems are based on Anglo-American common law. This paper addresses that argument by exploring the responsiveness of French and U.S. law to the needs of business enterprises during the nineteenth century, when both countries were undergoing industrialization. We find that contracting environment in the U.S. was in fact neither freer nor more flexible than that in France during this critical period. Not only did U.S. law offer enterprises a more limited menu of organizational choices, but business people in the U.S. had much less ability to adapt the basic forms to meet their needs than their French counterparts. Nor is there any evidence that American law evolved more readily in response to economic change than French law. In both nations, major changes in the rules governing organizational forms required the passage of new statutes, and governmental institutions do not seem to have worked any more expeditiously in the U.S. than in France to improve the menu of choices. To the contrary, it was not until the late twentieth century that U.S. business obtained much the same degree of contractual freedom that their French counterparts had long taken for granted.
\end{abstract}

\section{Acknowledgements}

The authors gratefully acknowledge the research assistance of Clothilde Canavate, Mark Dincecco, and Jennifer Wang, and the financial support of the Collins Fund, the UCLA Academic Senate, and the Guggenheim Foundation. We have also benefited from the advice of Hongbin Cai, Tony Freyer, Robert Gordon, Ron Harris, Timur Kuran, Gregory Mark, and Kenneth L. Sokoloff, as well as the comments of participants at seminars at the École des Hautes Études, Oxford University, Reed College, UC Berkeley, UCLA, UC Riverside, University of Southern California, and at the annual meeting of the American Association of Law Schools, the annual meeting of the American Society for Legal History, the Business History Conference, and at the CEPER conference on "Understanding Financial Architecture: Corporate Governance." 


\section{Legal Regime and Business's Organizational Choice: A Comparison of France and the United States during the Mid-Nineteenth Century}

Although there has long been widespread agreement that the effectiveness with which property rights are specified and enforced matters a great deal for economic growth, this idea has recently been pushed in a provocative direction by Rafael La Porta, Florencio Lopez-de-Silanes, Andrei Shleifer, and Robert W. Vishny (hereafter LLSV). According to these scholars, two alternative legal regimes — a common-law system based on judicial precedent and a civil-law system based on formal codes-emerged in Europe during the early modern period and were transplanted to the rest of the world through European expansionism. Reporting cross-country regressions for the mid-1990s, LLSV argue that the type of legal regime a country adopted at that time continues to affect its economic performance in dramatic ways. They find that countries whose legal systems are based on civil law (especially of French origin) have systematically weaker environments for business than those whose legal systems are based on Anglo-American common law: Common-law countries offer external suppliers of finance, whether shareholders or creditors, better protection than countries with legal systems based on French civil law. Moreover, firms' ability to finance their activities, whether measured by the ratio of stock market capitalization or debt to GNP, appears to be superior in common-law countries than in French civil-law countries, even controlling for the existence of protections to debt and equity holders and the quality of law enforcement in each country (LLSV 1997, 1998, and 1999). 
LLSV's findings touched off a heated debate that was waged primarily through alternative specifications for the cross-country regressions (Acemoglu, Johnson, and Robinson 2001; Levine, Loayza, and Beck 2000; Mahoney 2001; Beck, Demirgüç-Kunt, and Levine 2002 and 2003; Berkowitz, Pistor and Richard 2003; LLSV 2000; Botero, et al. 2002; Djankov, et al. 2003). They also gave rise to an effort to understand the apparent superiority of AngloAmerican law. ${ }^{1}$ Two main hypotheses have been offered to explain why code-based systems might have such inimical effects on economic growth. The first emphasizes the relatively static character of this type of legal regime. Under the Anglo-American system of common law, legal rules can evolve in accordance with businesses' needs. Codes, however, are revised relatively infrequently and, as a result, their provisions are likely to become increasingly outmoded as the economy develops (Posner 1973; Priest 1977; Rubin 1977; Beck, Demirgüç-Kunt, and Levine 2002). ${ }^{2}$ The second hypothesis is that the codes were creations of highly interventionist governments intent on consolidating their power over society. Whereas the French and German codes were imposed by Napoleon and Bismarck respectively, English common law was shaped by Parliament's struggle to limit the power of the King and so was more concerned with restraining government and protecting individual rights. LLSV favor this alternative and consider the existence of a civil code to be a proxy for bad government in the form of "an intent to build

\footnotetext{
${ }^{1}$ For an excellent survey of this literature, see Beck and Levine (2003).

${ }^{2}$ This idea of the superior flexibility of the common law has deep roots in the literature on comparative legal systems (see for example, Pound 1921; Stone 1936). It should be recognized, however, that some scholars have argued for the superiority of code-based regimes (Weber 1925/1954; Horn, Kötz, and Leser 1982), others have insisted that the differences between the two types of systems have been exaggerated or that they have diminished over time through a process of transplantation (Watson 1974), and still others claim that law in the French colonies was very different from that in France itself (Merryman 1996). For more comprehensive treatments of AngloAmerican versus French law, see Zweigert and Kötz 1998, and Glendon, Gordon, and Carozza 1999.
} 
institutions to further the power of the State" (LLSV 1999, 231-2; Glaeser and Shleifer 2002; Botero, et al. 2002). ${ }^{3}$

Both these explanations emphasize the different processes by which law is created and altered under the French and Anglo-American systems. These are topics that cross-sectional analysis is poorly suited to investigate, so we pursue a more historical approach in this article. In particular, we focus on France and the United States during the nineteenth century, when both countries were undergoing industrialization, and compare the extent to which their legal systems actually constrained businesses' organizational choices. We also compare the facility with which French and American legal rules evolved as the economy grew and developed.

France is an obvious case to study as it was the main producer of the codes singled out by LLSV for their detrimental effect on business. We study the United States, rather than Britain, because like France it was a "follower" nation in the timing of its industrialization. Moreover, the U.S. is a particularly appropriate case for our purposes because of its weak state, and because its decentralized structure of government, if anything, should have increased the flexibility of the common-law system relative to the civil-law codes that governed highly centralized France. An additional motive for focusing on the U.S. is that the most industrial of the American states were leaders in making corporate charters available to business enterprises, and it has generally been assumed that this leadership role extended to other organizational forms as well.

If legal regimes, as opposed to specific governmental policies, really mattered for economic growth, then their effects should be observable over long periods of time. It therefore follows that, if the Anglo-American system of common-law is intrinsically superior to French civil law, then U.S. businesses should have faced a freer, more flexible contracting environment

\footnotetext{
${ }^{3}$ This hypothesis too has a history that can be traced back at least to Friedrich A. Hayek (Hayek 1960 and 1973; North and Weingast 1989; Mahoney 2001).
} 
than French businesses in the nineteenth century as well as at the present time. Our research demonstrates, however, that the U.S. contracting environment was in fact neither freer nor more flexible than its French counterpart during this critical period of industrialization. Not only did U.S. law offer business people a more limited menu of organizational forms but the possibilities for adapting the basic forms to specialized needs were much greater in France than in the United States. Nor is there any evidence that American law evolved more readily in response to economic change than French law. On the one hand, our research suggests that the static nature of the French legal system has been overstated in the literature. On the other, we find the common-law to be more inherently conservative than many scholars have acknowledged. In both nations, major changes in the menu of available organizational forms, as well as in the rules governing these contracts, required the passage of new statutes. Although understanding the comparative political economy of legislation is beyond the scope of this article, we show that there is no evidence that governmental institutions in the United States worked more expeditiously than those in France to improve the contracting environment in which businesses operated. To the contrary, it was not until the late twentieth century that U.S. business obtained much the same degree of contractual freedom that their French counterparts had long taken for granted.

\section{The Corporation and Alternative Organizational Forms}

On the surface, it might appear that mid-nineteenth-century U.S. firms had a more favorable menu of organizational choices than French firms because they could readily adopt the corporate form. In France, businesses could not organize as corporations without the (difficultto-obtain) approval of the government until 1867, and in fact only 642 corporations were 
chartered between 1807 and 1867 (Freedeman 1979 and 1993, 1-9). Although initially U.S. firms also needed special permission (in the form of a legislative act) to organize as corporations, by the second quarter of the century a number of states had made it easier for firms to obtain charters, and by mid-century most of the leading industrial states had passed general incorporation laws that routinized the entire process (Evans 1948; Hurst 1970; Maier 1993; Blair 1993). Not surprisingly, the number of corporations formed in the United States during the first two-thirds of the nineteenth century was much greater than in France. In New England, for example, more than 3,200 were organized between 1800 and 1843, and in excess of 3,500 between 1844 and 1862 (Kessler 1948, 46) — that is, in this region alone more than ten times as many corporations were organized as in the whole of France over approximately the same period.

It has generally been thought that the limited liability associated with the corporate form was crucial for access to broad capital markets and that the lack of a general incorporation law in France until 1867 was an important barrier to industrialization. As a matter of fact, however, relatively few of the manufacturing corporations chartered in the U.S. during the nineteenth century raised funds by selling shares on the market. Although more than three thousand industrial corporations had been chartered in New England by 1875, the Boston market quoted stock prices for only about fifty. According to a contemporary survey of trading on the Boston exchange, manufacturing stocks generally were held by people who did not intend to sell them. As a result, "it was exceedingly difficult to obtain reliable quotations," even for the region's largest enterprises, because the securities rarely appeared on the market "except in stray shares or in the case of executors' sales." (Martin 1898, 126-32). Even fewer manufacturing stocks were traded in New York, the nation's primary financial market (Navin and Sears 1955; Baskin and 
Miranti 1997). As late as 1890, the Commercial and Financial Chronicle reported financial information for only about fifteen industrial enterprises and quoted stock prices for less than half of those.

The difficulties that French firms faced in forming corporations were not as significant as they are often made out to be, moreover, because the Code de Commerce offered business people an important alternative: the société en commandite, or limited partnership. (In both France and the United States, of course, businesses could also organize as ordinary partnerships). A descendent of the medieval Italian commenda, the limited-partnership form was sanctioned by Colbert's Ordinance of 1673 and explicitly defined and regulated by Napoleon's Code of 1807. Sociétés en commandite (simples) consisted of one or more general partners, who managed the firm and were unlimitedly liable for its debts, and one or more special partners, whose liabilities were limited to their investments and who played no role in management (see Table 1). An important advantage of the form was that it enabled the general partners to raise funds from wealthy individuals who were not interested in participating actively in the business (Rivière, 1882, 80-81; Lyon-Cahen and Renault 1924, 112-14; Howard 1932; Houpin and Bosvieux 1935, Vol. 1, 368; Ripert 1967, 456-58).

These limited partnerships could take a variety of forms, and, by the third decade of the nineteenth century, some had even begun to issue transferable shares. In 1830, a group of disgruntled shareholders challenged the legality this practice on the grounds that it was not explicitly permitted by the Code de Commerce. Loosely constructing the Code's provisions, both the Commercial Tribunal of Paris and, on appeal, the Royal Court upheld the practice. Over the next couple of decades the number of commandites par action, as these enterprises were called, grew rapidly until the passage of legislation in 1856 that more strictly regulated the 
issuance of shares and strengthened stockholders' rights with respect to the managing partners (Freedeman 1979). New legislation in 1863 permitted firms with a maximum capital of 20 million francs to organize as corporations without receiving special permission from the state. When the 1867 general incorporation law removed the limit on capitalization, the number of corporations (sociétés anonyme) grew rapidly. Initially, corporations seem to have reduced the popularity of commandites simples, as well as commandites par action, but the former soon regained its earlier position. Between 1880 and 1913, however, the growth in the number of corporations (which now accounted for about 20 percent of new multiowner firms) came at the expense of partnerships (see Figure 1).

As in the case of the United States, relatively few of the new corporations chartered under the general law (indeed, only 19 of the nearly 800 formed between 1867 and 1875) were listed on the official exchange. Nonetheless, French firms seem to have had readier access to national capital markets than their American counterparts. Because government approval was needed to list a security on the Paris Bourse, the shares of many enterprises traded instead on the coulisse (curb market). By 1875, there were frequent quotations for more than 300 enterprises (not including banks, insurance companies, and railroads). At a time when quotations were available for no more than a handful of industrial firms in New York and for only about 50 in Boston, at least 208 of the firms whose securities were actively traded in Paris can be identified as manufacturing enterprises. Many, moreover, were commandites par actions rather than corporations (Plache 1999; Hautcoeur 1994, ch. 2).

Although there were attempts to introduce the commandite form into the United States during the early nineteenth century, the idea never took off. New York passed an enabling statute in 1822, and most other states followed its example over the next decade or so. The 
statutes, however, were much more restrictive than the provisions of the French Code. For example, all members of a limited partnership had to sign a certificate (to be filed with a government authority) declaring among other things the amount of their individual investment, so there was no possibility of issuing tradable shares. Moreover, because the innovation did not fit well with the body of common-law precedent, the courts interpreted the statutes conservatively in ways that potentially exposed limited partners to unlimited liability. For example, they tended to view any deviation from the declarations contained in the partnership certificate as sufficient cause to hold all of the partners unlimitedly liable for the firm's debts, even partners who were innocent of error and even if the substance of the deviation was inconsequential (Howard 1934; Lewis 1917; Warren 1929, ch. 6). ${ }^{4}$ Not surprisingly, the form was comparatively rarely used. A sample of over 160 partnerships for which the R. G. Dun Company collected credit information in Boston during the 1840s and early 1850s included only two with limited partners. ${ }^{5}$ Similarly, a search by Stanley Howard of the records of five New Jersey counties (representing about a third of the population of the state) from the 1830s until the 1930s yielded only about 140 limited partnerships (Howard 1934).

Comprehensive data on business forms are not available for the U.S. for the nineteenth century, but Jeremy Atack and Fred Bateman used the names of firms enumerated in the Census of Manufactures to estimate that partnerships of all kinds accounted for nearly 90 percent of multi-owner firms during the period 1850-1870 (Atack and Bateman 1995). In 1900, the first year the Census recorded information on organizational form, 67 percent of all manufacturing

\footnotetext{
${ }^{4}$ By the end of the century, a few states (mainly in the western parts of the country) had passed legislation protecting special partners who were not involved in the misstatement. See Gilmore 1911, 618-19.

${ }^{5}$ The sample consisted of every firm on the right hand page of Massachusetts, Vol. 67, that had an entry that began before 1853. The records of the R. G. Dun Co. are located at Baker Library, Harvard University Graduate School of Business Administration.
} 
establishments owned by more than one person were partnerships (including limited partnerships) and 29 percent were corporations, with the remaining 4 percent consisting mainly of cooperatives (U.S. Census Office 1902, 503). Economy-wide counts are not available until after 1916, when the Internal Revenue Service began to collect the income tax. In 1920, there were approximately 314,000 corporations in the United States compared to about 241,000 partnerships, again including limited ones. These figures likely understate the use of partnerships because all corporations were required to file tax returns whereas partnerships only had to file if their income exceeded the threshold for the tax (U.S. Internal Revenue Service 1922, 8-10). The number of limited partnerships, however, was clearly very small—so small that the IRS did not bother to count them separately until 1976, at which point they constituted only 7.0 percent of all partnerships and 2.7 percent of partnerships in the manufacturing sector ((U.S. Internal Revenue Service 1979, 408). The bottom line is that multi-owner firms in the United States, unlike those in France, effectively had only two organizational choices during the era of industrialization: ordinary partnerships or corporations.

\section{Flexibility within Organizational Forms in France}

Not only did French firms have a broader range of organizational choices, they also had considerable freedom to modify the basic forms to suit their needs. As a result, for them liability was essentially a continuous variable rather a dichotomous choice. The French legal system even allowed members of ordinary partnerships (sociétés en nom collectif) to limit the extent of the risks they assumed. Business people who organized partnerships under the terms of the Code were required to draft formal written agreements, the main details of which had to be registered with the government and published in a newspaper of record. Because the provisions of these 
agreements were public knowledge, partners had a great deal of freedom to specify the terms of their relationships. Although many firms organized under the Code gave all partners equal rights and responsibilities, others added to their agreements clauses that limited the capacity of one or more of their members to act on behalf of the firm. So long as these clauses were published in the requisite journal, they were enforced by the courts. If a partner who was not authorized to do so borrowed money on behalf of the firm, the firm was not obligated to repay the debt (LyonCahen and Renault 1924; Houpin and Bosvieux 1935, Vol. 1; Merle 1998). ${ }^{6}$

There is abundant evidence that business people took advantage of this flexibility to control their liabilities. During the years 1832-1843, for example, 27.0 percent of the new partnerships that published notices of their formation in the Paris newspaper of record, the Gazette des tribunaux, delegated managerial authority to a subset of their members (see Table 2). About the same proportion (25.0 percent) required that debt instruments be signed by more than one member of the firm, and 7.7 percent prohibited partners from incurring any debts whatsoever. As Table 2 indicates, moreover, the value of this flexibility appears to have increased with the number of partners. Whereas over half of the firms (51.1 percent) with only two partners did not in any way restrict the ownership rights of members, only 7.6 percent of the firms with more than four partners had similarly permissive governance rules.

The other organizational forms to which French business people had access were equally flexible. The managing partners of a commandite, for example, could and did organize themselves with as much diversity as if they had been members of a simple partnership (see Table 3). For example, of the 412 commandites simples in our dataset that had multiple managing partners, 42.7 percent imposed some kind of restriction on management, and 10.1

\footnotetext{
${ }^{6}$ Contract clauses that required partners to fulfill obligations to the firm (for example, make promised infusions of capital) were enforceable even if they were not published.
} 
percent completely prevented the managing partners from borrowing, in effect requiring the approval of the silent partners for the firm to take on debt. Commandite contracts could also require the managing partners to render accounts to the silent partners on a regular basis, and they could require that the managing partners pay out a minimum dividend each year (generally between 4 and 6 percent) to guarantee the silent partners at least a fixed return on their investment. As in the case of ordinary partnerships, moreover, the value of this flexibility appears to have increased with the size of the firm.

There were, of course, limits to what organizers of commandites simples could do: at least one partner had to be fully liable; shares were not tradable; and the only way to replace a managing partner was to dissolve the firm and form a new one. The last two of these limitations could be overcome (without giving up any of the flexibility of the societé en nom collectif or commandite simple) by organizing the firm as a commandite par actions (see Table 4). Not only were the shares of these ventures tradable, but shareholders could appoint a conseil de surveillance, or supervisory committee. In some cases the conseil was simply a communication device between managers and shareholders, but in others it acted as a board of directors whose approval was required for important decisions, such as whether to encumber the firm. (The latter role became more common over time, especially after an 1856 law made the creation of a conseil mandatory). ${ }^{7}$ Shareholders of commandites par actions might also hold regular annual or biannual meetings at which they could fire the manager or change other aspects of the organization. Between 1832 and 1843 there were 227 shareholder meetings that resulted in

\footnotetext{
${ }^{7}$ Unfortunately, the Code did not require firms to publish the articles of their contracts relating to internal policing. Nonetheless, information about conseils de surveillance can be gleaned from notices of amendments to contracts for existing commandites par action. The conseils could range in size from three to seven members; their meetings could occur quarterly or be as frequent as once a week; their powers could be limited to auditing the books, or their approval could be required to sell assets and/or incur debts.
} 
modifications to the firm. 108 of these resulted in the appointment of new managers. Organizers could also specify which types of shareholders could attend these assemblies and what voting rules would be employed - that is, whether there would be one vote per share, one vote per shareholder, or some intermediate scheme. In addition, they could require that managers pay shareholders a minimum dividend rate before profits could be used for any other purpose.

Abuses during the boom of the 1850s moved legislators to attempt to regulate the use of share commandites. In so doing, they sought to balance two contradictory goals. On the one hand, they aimed to keep limited partners out of the day-to-day affairs of the firm. On the other, they did not wish to give insiders (the managing partners and members of the conseil) unrestricted power to do as they pleased. The 1856 law tried to resolve this dilemma by imposing personal liability on members of the (now mandatory) conseils if they did not perform their duties properly (Rivière 1882, 90). This solution proved unsatisfactory, however, because shareholders were not willing to serve on such boards if they bore personal liability (LefebvreTeillard 1985). As a consequence, the general incorporation law of 1867 took a different tack. It required shareholders to elect audit committees and allowed them to assume a more active role in the affairs of the enterprise. At the same time, it absolved those who served on these committees of personal liability for the firm's obligations (Hautcoeur, 1994, 247-8).

Under the 1867 act, firms still had considerable freedom to determine their governance structures and how they would meet the requirements of the law. Indeed, incorporators still had all of the choices that had been available to organizers of commandites par action, including the ability to distinguish different types of shares, set voting rules for stockholders, determine the timing of regular shareholders' meetings (as well as the circumstances under which extraordinary meetings could be called), and fix a minimum level for dividends. French business people thus 
could obtain the advantages of incorporation without any significant loss of contractual flexibility.

\section{Lack of Flexibility in the United States}

Business people in the United States had much less ability than their French counterparts to modify the basic organizational forms to meet their needs. Under Anglo-American common law, for instance, partnerships were defined by the relationship of the parties to each other rather than by the existence of a contract. If two or more business people agreed to share the profits from a venture, then they were partners. There was no requirement that they enter into a formal contract and no requirement that they notify the public of their relationship. This simple principle had two profound consequences. First, it meant that business people could be held by a court to be partners even if they had not entered into a partnership agreement and did not consider themselves to have formed a firm. ${ }^{8}$ Second, because partnerships were not legal entities under Anglo-American common law, the firm had no existence or identity that was independent of the people who made it up. Each partner exercised full ownership rights and could enter into debt contracts that were binding on the firm without consulting the other members. Although business people could draw up copartnership agreements that restricted the ability of individual partners to contract debts on behalf of the firm, these agreements were private arrangements and not matters of public record. As a consequence, they were not legally binding with respect to third parties who had not been given formal notice of their terms. Partners often did negotiate

\footnotetext{
${ }^{8}$ This ambiguity in the law generated large amounts of litigation during the early nineteenth century, especially during downturns, as creditors desperately sought to collect on the obligations of failed businessmen. Over time, new legal tests evolved that reduced the risk of being held liable as a partner for contracts that were not intended to be partnerships but involved some sharing of profits (Lamoreaux 1995).
} 
such agreements, but if a member obligated the firm in violation of the partnership contract, the other partners were likely nonetheless to be held liable for the debt (Story 1859; Warren 1929, ch. 1). As John Marshall, Chief Justice of the U.S. Supreme Court, explained in Winship v. The Bank of the United States (30 U.S. 529 [1831]), “The articles of copartnership are . . rarely if ever seen, except by the partners themselves. ... The trading world, with whom the company is in perpetual intercourse, cannot individually examine these articles, but must trust to the general powers contained in all partnerships."

Although, in theory, a partner might seek an injunction in equity against a member of the firm who violated a partnership agreement, such a remedy could do little more than force the dissolution of the partnership and a settlement of accounts (Story 1859, 352). This is not to say that such contracts were useless. At the very least, they provided written evidence of the rules to which partners expected each other to adhere. Perhaps more important, the threat of dissolution gave partners some ability to discipline each other's behavior-particularly if the threat was made by the wealthiest member or if there was a chance that dissolution would require the liquidation of assets whose value outside the firm was much lower than within. ${ }^{10}$ Clearly, however, this method of discipline was inferior to the ability to enforce the terms of the contracts themselves that French businesses obtained under the Code.

Business people in the United States could, of course, turn to the corporate form as a remedy for the deficiencies of partnerships. Because all members of a corporation had limited

\footnotetext{
${ }^{9}$ The courts did sanction one means of concentrating management (and the right to encumber the firm) in a partnership: the joint stock company. Members of joint stock companies, however, were still fully liable for the enterprises' debts in the absence of explicit contracts with creditors to the contrary, and there was considerable uncertainty about whether the courts would enforce all aspects of the contract (Warren 1929, 327-404; Blair 2003).

${ }^{10}$ The threat of dissolution, of course, could also be used by one member of a firm to hold up the others (Blair 2003), but the possibility that the threat would result in liquidation acted as a constraint because the recalcitrant member would have to bear his or her full share of the costs of liquidating firm-specific assets (Lamoreaux 2003).
} 
liability, stockholders did not have to negotiate special side contracts in order to protect assets held outside the firm. ${ }^{11}$ In addition, because the corporate form concentrated managerial authority in an elected board of directors, only those persons explicitly authorized by the board could encumber or otherwise act on behalf of the firm. Contracts negotiated by any other stockholder were unenforceable (Freund 1896; Blair 2004).

At the same time as incorporation solved some of the agency problems associated with partnerships, however, it also created new problems - problems that were potentially exacerbated by the increasingly standardized nature of the form in the United States. During the early period when corporate charters could be granted only by special legislative act, their terms varied significantly from one enterprise to the next. For example, some charters allowed stockholders one vote for each share owned, but others specified one vote per share up to some ceiling, and some even gave each stockholder the same vote regardless of his or her holdings. As the number of corporate charters increased, legislatures developed standard templates that made the provisions much more uniform. The passage of general incorporation laws further reduced the

\footnotetext{
${ }^{11}$ The earliest corporate charters in the United States were often silent on the issue of stockholders' liability, creating considerable uncertainty that, by the second decade of the nineteenth century, was resolved by the courts in favor of the presumption of limited liability. Where early charters were not silent, they sometimes explicitly denied stockholders this privilege. Over time, however, limited liability came to be treated as a standard aspect of the corporate form, though charters for railroads and banks might still make shareholders liable up to double the par value of their stock (Livermore 1935; Handlin and Handlin 1945 pp. 8-17; Dodd 1954, pp. 365-437; Horwitz 1992, p. 94; Perkins 1994, pp. 373-76). Of course, even with limited liability stockholders of small corporations often found that they had to assume personal responsibility for their enterprises' debts in order to secure loans at affordable rates (Woodward 1985; Forbes 1986) Nonetheless, this attribute of incorporation did resolve to an important degree the principal-agent problems that partners faced vis-à-vis each other by removing the possibility that one member of a firm could unilaterally encumber the enterprise with debts which the others might have to repay out of their own assets. In a firm with limited liability, members were responsible personally only for obligations that they deliberately chose to assume.
} 
extent of variation, so that by mid century most charters specified one-vote-per-share, majorityrule governance (Dunlavy 2004).

This standard governance rule was a potential source of agency problems because it weakened the position of minority shareholders and potentially subjected them to exploitation by shareholders controlling a majority of the stock. If the majority followed policies that members of the minority thought were wrongheaded or detrimental to their interests, in the absence of outright fraud there was little the latter could do but grin and bear it. Minority shareholders could not force a dissolution. Nor could they easily exit by selling their shares. Indeed, in the case of closely held corporations, often the only buyers for their shares were the same majority shareholders with whom they were in conflict - a situation conducive more to extortion than to an equitable resolution of the problem (Hetherington and Dooley 1977; Hillman 1982; Dickinson 1984; Mitchell 1990; Moll 2000; Lamoreaux 2004).

Of course, voting rules that limited the power of the majority could also cause problems by giving minority shareholders the ability to hold up the majority (Rock and Wachter 2000; Blair 2004), but it is not obvious that one-vote-per-share, majority-rule governance schemes are always superior. Presumably the desirability of alternative rules would vary from one firm to the next depending, for example, on the role played by minority shareholders in the ongoing success of the enterprise. Where members of the minority contributed critical human capital, it might be important to give them a voice disproportionate to their shareholdings. The competitive position of the Edison Electric Light Company was undermined, for example, by Thomas Edison's dissatisfaction with the business strategy embraced by J. P. Morgan and other major stockholders. At one point, Edison waged a costly proxy battle to wrest control of company from Morgan, only to lose it again. Ultimately, the company's successor, Edison General Electric, 
merged with the more profitable Thomson-Houston Company to form General Electric (McGuire, Granovetter, and Schwartz 1993; Carlson 1995). ${ }^{12}$

Minority shareholders in corporations sometimes attempted to protect themselves by means of side contracts. As in the case of partnerships, however, these contracts were often unenforceable. For example, there was a high probability that agreements that required shareholders' unanimity (or even a super-majority vote) for corporate decisions would be overturned (Hornstein 1950 and 1953; Cary 1953; O’Neil 1953, 1958, and 1965; Gower 1956). ${ }^{13}$ Even worse, shareholders who ignored or altered the standard governance rules in such ways risked being held partners and thus unlimitedly liable for their firms' debts. As New Jersey's Chancellor warned in 1852, if firms operating for all practical purposes as partnerships were allowed to exercise corporate privileges like limited liability, the result would be to perpetrate "a fraud upon the community." In the case at issue, two shareholders held all of the stock of the New England Manufacturing Company, excepting four shares, "which were put in the names of four other persons, merely for the purpose of having a sufficient number of stockholders to organize the company in the manner directed by the act of incorporation.” After incorporation, the two major owners continued to run their business "as before ..., by and between themselves as individuals, the company not acting by its board." In the Chancellor's view, the business was "in reality but an ordinary partnership." Therefore, either the members of the firm "must be held to conduct their business as a corporation, and be governed by the law of corporations," or they

\footnotetext{
${ }^{12}$ Another similar episode involved the Edison United Phonograph Company. Edison had assigned his phonographic patents to the firm in exchange for half of its stock. Later, he found himself in disagreement with the policies pursued by the majority of the firm's directors and was unable to persuade them to change course. Frustrated, he sued in equity to try to force the dissolution of the firm, but the court refused to intervene (Edison $v$. Edison United Phonograph Co., 52 N.J. Eq. 620 [1894]).

${ }^{13}$ The reader will note that these sources all date from the post-World War II period. Even that late there was substantial uncertainty associated with agreements that modified the standard governance rules. See below.
} 
"should be liable to debts to the whole amount of their property" (Vandyke v. Brown, 8 N.J. Eq. $657[1852])$

Although the courts would not permit stockholders to opt out of the standard corporate governance rules, they did usually allow stockholders to contract among themselves to exercise their votes in particular ways. ${ }^{14}$ For example, the courts were willing to enforce agreements among stockholders to vote for particular persons as directors or to place their stock in voting trusts whose officers in turn would choose the directors of the firm. Thus a federal court declared in 1867 that it was "unable to perceive anything . . . contrary to public policy, or anywise open to objection" in an agreement by a group of stockholders to place their shares in an irrevocable voting trust for a specified period of time (Brown v. Pacific Mail Steamship Co., 5 Blatchf. 525 [1867]). Similarly, an Illinois court saw nothing wrong in an agreement among a majority of the shareholders of the Chicago Carbon and Coal Company to "determine among themselves as to the officers and management of the company, and that if they could not agree, they would ballot among themselves for the directors and officers, and that the majority should rule, and their vote be cast as a unit, so as to control the election" (Faulds v. Yates, 57 Ill. 416 [1870]). As this last example suggests, such agreements could actually worsen the situation of minority shareholders by making it easier for a controlling group to solidify its power. Moreover, even when such contracts were employed by the minority to protect their interests, there were limits to their reach. Most importantly, they could not be used to bind the directors to pursue a particular set of policies or elect specific people as officers. The courts regarded such provisions as "contrary to

\footnotetext{
${ }^{14}$ There were, however, some contrary decisions. See, for example, Seitz v. Michel,148 Minn. 80 (1921): “There is much authority tending to sustain plaintiff's contention that the owners of a majority of the stock of a corporation may combine, either through the agency of a voting trust or by private agreement, to secure and retain control and ensure permanency in the management of corporate affairs. There is nearly as much authority condemning all such combinations and private arrangements as contrary to public policy.
} 
public policy" and would refuse to enforce them if the directors violated their terms (Guernsey $v$. Cook, 120 Mass. 501 [1876]; Cone v. Russell, N.J. Eq. 208[ 1891]; Manson v. Curtis, 223 N.Y. 313 [1918]).

In sum, business people in the United States not only had fewer organizational choices than their French counterparts, they also had less freedom to modify the basic forms to suit their needs. Although they sometimes attempted to compensate for this rigidity by writing side contracts, the case law indicates that many such agreements were often either unenforceable or of uncertain effect. Because these kinds of contracts were private matters, we have no way of estimating their incidence, but there is little question that there were generally an inferior means of obtaining the flexibility that French business people obtained under the Code.

\section{Change over Time in Response to Industrialization}

Because French businesses had a broad range of organizational choices and could readily modify the basic forms to suit their needs, one would not expect industrialization to have generated much pressure for additional flexibility. Changing economic conditions and periodic bouts of speculative excess did, however, result in repeated calls for new legislation, particularly reforms that would protect small investors in sociétés anonymes. Some of these calls ultimately led to the passage of statutes. For example, a reform effort that began in the mid-1880s finally

yielded an 1893 law specifying (among other provisions) that the original subscribers of a corporation were liable for calls on capital for two years, even if they sold off their stock, and that shares had to be fully paid in before they could be designated bearer shares. But subsequent proposals in 1903, 1906, and 1911 failed even to get to the floor of the Chamber of Deputies for 
a vote (Freedeman 1993; Lyon-Cahen and Renault 1924, 11; Houpin and Bosvieux 1935, Vol. 1, $767-68) .{ }^{15}$

French corporations were required by law to deposit financial statements with their local commercial tribunals. In principle, shareholders could research these statements, but the lack of accounting standards meant that the information they contained could obscure as much as it revealed about a company's actual condition. Although the state increased penalties during the 1930s for firms that did not file financial statements, it made no effort to standardize accounting practice or force firms to publicize their balance sheets. Nor did the governing authority of the Bourse make any effort to increase transparency (Ripert 1967, Vol. 1). Not until the wholesale redrafting of business law in 1966 were there substantial changes in the provision of information to investors in sociétés anonymes. These reforms ushered in a period of convergence towards U.S. standards of corporate governance. Indeed, the laws that created the Commission des Operations de Bourse and required that publicly traded corporations publish financial statements drew inspiration from the legislation that had set up the Securities and Exchange Commission (SEC) in the mid-1930s (Merle 1998, 553).

Business people involved in small privately held enterprises, however, received a boost in 1925, when the French government added a major new alternative to the menu of organizational forms - the limited liability company or société à responsabilité limitée (SARL). Based on the model of the German Gesellschaften mit beschränkter Haftung $(\mathrm{GmbH})$, this option mixed

\footnotetext{
${ }^{15}$ Sometimes, when problems developed that were not quickly resolved by new legislation, the French courts articulated their own rules, much like common-law courts in the United States. For example, in the late nineteenth century they determined that acts of corporations that involved fundamental departures from the terms of their original charters required the unanimous approval of stockholders rather than the simple majorities sufficient for minor alterations. The courts also decided what kinds of changes should be construed as fundamental, applying a broad definition that included most mergers until new legislation in 1913 provided a narrower standard (Freedeman 1993).
} 
attributes of corporations and partnerships. For example, all members of an SARL had limited liability, but the capital was not divided into tradable shares. The new form apparently served an important economic need because businesses rapidly adopted it (see Figure 2). Despite the ready availability of the corporate form, as late as 1920 to 1925 two-thirds of all the new multi-owner firms formed in France were ordinary partnerships, and three-fourths had at least one liable partner. Within a few years of the passage of the new statute, the numbers had completely reversed. By 1927 to 1932, fully 87 percent of all new multi-owner firms were either corporations or SARLs - that is, forms that granted all members limited liability. Moreover, of these limited-liability firms, three quarters were organized as SARLs rather than sociétés anonymes. $^{16}$

Intriguingly, although the limited liability company was already in widespread use in Great Britain, as well as in Germany, the 1925 law was not a response to pressure from the French business community for access to this advantageous form. Nor was it an attempt by progressive policy makers to copy models that had achieved desirable results elsewhere. Rather, the statute was a consequence of France's recovery of Alsace and Loraine after the First World War. These departments had been part of Germany and hence governed by German law since the Franco-Prussian War. Many businesses had organized during this period as GmbHs and did not want to give the form up when the area returned to French control. Instead, they campaigned for legislation that would make an equivalent form available throughout France. Despite the measure's subsequent popularity, the bill faced staunch opposition which delayed its passage

\footnotetext{
${ }^{16}$ These figures come from annual issues of the Compte général de l'administration de la Justice Civile et Commerciale and include all new multi-owner firms registered in France. The results for Paris alone are similar: Ordinary partnerships accounted for 69 percent of new multi-owner firms in 1920-25; addition of commandites would increase the figure to 83 percent. For 1927-32, 87 percent of firms in Paris were either corporations or SARLs and of those 65 percent were SARLs.
} 
until 1925 (Copper-Royer, 1925, Vol. 3, 173-74; Houpin and Bosvieux 1935, Vol. 2, 752, 753 fn 1; Ripert 1968, 476-77).

In the case of the United States, one might have expected businesses' relative lack contractual freedom to have generated pressures for more organizational choice, but the pace of change was glacial until the last third of the twentieth century. Not only did the common law fail to evolve in ways that increased the flexibility of the legal rules governing business organizations, but at times it even functioned as a barrier to statutory reform. For example, not only was there no change in the rule that contracts that limited the ability of one member of a partnership to encumber the firm were not enforceable if creditors failed to receive advance notice of the restrictions, but the weight of common-law precedent derailed an effort to draft legislation that would have made the partnership form more flexible. During the first decade of the twentieth century, as part of the movement to standardize legal practice across states, the Conference on Uniform State Laws directed its Committee on Commercial Law to prepare a Uniform Partnership Act. The Committee commissioned two drafts: one based on common-law precedent; and the other on the idea, central to the French Code, that partnerships were legal entities. Because the latter statute would have required partnerships to publish notice of their formation, it had the potential to grant American business people the same ability that their French colleagues enjoyed to write contracts controlling the extent of their liability. At the start of the drafting process, there was overwhelming sentiment for the French approach, but in the end the draft based on common-law precedent prevailed. One of the primary reasons was the growing realization that such a statute would "abolish much of our existing partnership law and substitute in its place radically different legal principles ...” (Lewis 1915, 172) Although eventually a Revised Uniform Partnership Act would declare partnerships to be legal entities, 
this change would not occur until 1992, and even then most states would balk at accepting it (Hurst 1996).

In the case of corporations, there was similarly little evolution in the courts' attitude toward stockholders' agreements that altered the standard governance rules. Thus the New Jersey Appeals Court decided a key case in 1910 on much the same grounds that the state's Chancellor had articulated over a half century earlier in Vandyke v. Brown. At issue was a corporation organized by Walter M. Jackson and Horace E. Hooper to publish and distribute the Encyclopedia Britannica. As in the earlier case, the two men had agreed between themselves to run the business as a partnership in which all decisions were to be made by mutual assent. When they had a falling out, Jackson sued in equity to enforce the agreement. The court turned him down, adamantly declaring that partnerships and corporations were different legal forms and that business people could not "Proteus-like" become "at will a co-partnership or a corporation, as the exigencies or purposes of their joint enterprise may from time to time require."

If the parties have the rights of partners, they have the duties and liabilities imposed by law, and are responsible in solido to all their creditors. If they adopt the corporate form, with the corporate shield extended over them to protect them against personal liability, they cease to be partners, and have only the rights, duties, and obligations of stockholders (Jackson v. Hooper, 76 N.J. Eq. 592 [1910]).

This rigid view of the rules of corporate governance persisted at least until the mid-twentieth century. As late as 1945, for example, the New York State Court of Appeals struck down a corporate by-law requiring stockholders' unanimous consent for the election of directors on the grounds that "the State, granting to individuals the privilege of limiting their individual liabilities 
for business debts by forming themselves into an entity separate and distinct from the persons who own it, demands in turn that the entity take a prescribed form and conduct itself, procedurally, according to fixed rules" (Benintendi v. Kenton Hotel, 294 N.Y. 112 [1945]). ${ }^{17}$

Although state legislatures passed a number of revisions to their general incorporation laws during the late nineteenth and early twentieth centuries, the collective effect of these changes at least through the first half of the twentieth century was to increase the power of majority shareholders over the minority. For example, a wave of statutes enacted in the wake of New Jersey's permissive 1888 law typically included provisions that reduced the ability of individual stockholders to block managerial decisions that fundamentally altered the business of the enterprise. ${ }^{18}$ As one writer put it, the result was increasingly to place the individual stockholder "in the position of holding a "pig-in-a-poke" — to make him or her "more dependent with each new statute upon the desires of the management and the majority which often is only another name for the management" (Rutledge 1937, 312, 337; Berle and Means 1933; Dodd 1936; Dickinson 1984).

Stockholders also found it increasingly difficult to monitor their investments. Although some early general incorporation laws (most notably New York's widely copied 1848 statute) had required corporations to issue annual financial statements, reporting requirements tended to become laxer over time. Indeed, by the turn of the century, except in the case of special types of corporations like banks, the statutes rarely included mandates to provide information on

\footnotetext{
${ }^{17}$ Although some decisions (see, for example, Ripin v. U.S. Woven Label Co., 205 N.Y. 442 [1912]) pointed toward a more flexible view of the statutory requirement, Clark v. Dodge, 269 N.Y. 410 (1935) was the first case to articulate the view that a contract among stockholders that deviated from statutory norms might be upheld so long as it "damaged nobody—not even, in any perceptible degree, the public." See Dickinson (1984).

${ }^{18}$ As in France, the courts tended to hold that important changes to a corporation's charter required stockholders' unanimous consent. By the late nineteenth century, however, the courts increasingly were permitting firms to liquidate and reorganize in order to bypass recalcitrant shareholders (Carney 1980).
} 
performance to stockholders, let alone publish balance sheets or profit and loss statements. Stockholders generally retained a common-law right to examine their enterprise's books, but this right was difficult and expensive to exercise. Moreover, it did not extend to those trying to decide whether or not to buy a firm's stock. Not until the creation of the Securities and Exchange Commission in the 1930s was there much in the way of government protection for external investors, but even then the only shareholders who benefited were those putting their money into corporations whose securities were traded publicly (Kuhn 1912; Dodd 1936; Cadman 1949; Gower 1956; Hawkins 1986; Baskin and Miranti 1997).

The plight of minority investors in small- or medium-sized firms received scant attention until the New York legislature responded in the late 1940s to the Benintendi decision by passing a law allowing stockholders in close corporations to set high voting and quorum requirements for corporate decisions (O’Neal 1978, 874). Other states, however, were much slower to take action. North Carolina imbedded several provisions in its 1955 Business Corporation Act that were aimed specifically at small, closely held firms, including one declaring that agreements among all the shareholders of such corporations shall not, regardless of their form or purpose, "be invalidated on the ground that [their] effect is to make the parties partners among themselves" (O’Neil 1965). A few other states passed similar statutes over the next decade or so, after which the trickle finally became a torrent. Around the same time states also began to pass new laws that defined and established legal remedies for "corporate oppression" and other similar torts (Hillman 1982; Dickinson 1984; Mitchell 1990).

During the late $1980 \mathrm{~s}$, moreover, states took steps to increase the menu of organizational choices. A first wave of statutes made possible the formation of Limited Liability Companies 
(LLCs) along the lines of the French SARLs; ${ }^{19}$ a second added the option of Limited Liability Partnerships (LLPs), making it possible for every member of an ordinary partnership to limit their liability for the firm's future debts simply by filing appropriate notice (Bishop 1995; Ribstein 1996; Stover and Hamill 1999; Banoff 2002). Although these changes owed more than anything else to attempts by firms to reduce their increasingly burdensome income tax liabilities, the result was to expand in a sudden and dramatic way the contractual freedom of business people in the U.S. By the start of the twenty-first century, firms could both secure limited liability for all their members and choose among a broad range of governance structures—much as their French counterparts had been able to do since the mid nineteenth century.

\section{Does Legal Regime Matter?}

Except for its reluctance to charter corporations before 1867, there is no evidence that the centralized French state operated as more of a constraint on businesses' organizational choices than the decentralized American state. To the contrary, until recently French business people had a broader menu of organizational forms from which to choose than their U.S. counterparts. They also had much more ability to modify the basic forms to suit their needs. Although the

\footnotetext{
${ }^{19}$ A few states had earlier passed legislation to enable business people to form limited liability associations. In 1874 , for example, Pennsylvania passed a law providing for the creation of a new form of enterprise called the limited partnership association. Michigan followed suit in 1877, New Jersey in 1880, and Ohio in 1881, but the device did not spread beyond these four, heavily industrial states. Moreover, even in these states the form was rarely adopted, most likely because the governance structure dictated by the legislation was highly restrictive. The statutes vested the power to incur debts in a board that had to consist of at least three managers elected by the members of the firm. Debts in excess of $\$ 500$ required the signature of at least two managers, and there were situations in which the prior approval of a majority of the members was required before the managers could take action. Approval of a majority was also necessary for the transfer of shares to new members (even from decedents to heirs) and for the acquisition of additional shares by an existing member (Schwartz 1965; Gazur and Giff 1991).
} 
trend in the U.S. was toward greater contractual freedom over time, the common law played little role in this evolution. Rather, in both countries, change came primarily through the passage of new statutes. In some periods and for some purposes, U.S. statutes were more advantageous than the French, but in other periods and for other purposes, French statutes had the edge. Moreover, the trend over time was for U.S. law to converge toward the French model of organizational choice rather than the reverse.

Before we succumb to the temptation to trumpet the advantages of the French legal regime over the Anglo-American system, it is instructive briefly to add the case of Great Britain to the comparison. In some ways the situation facing British businesses in the nineteenth century was similar to that of firms in the U.S. For example, in both countries the partnership form was governed by the common law. Moreover, if anything, the law of partnership in Britain was more unchanging and inflexible. Not only was there little evolution in the basic legal rules governing partnerships, but the weight of precedent blocked the introduction of the limited partnership form in Britain even more effectively than it did in the U.S. (Gower 1953 and 1956; Harris 2000).

After Parliament passed a series of progressively more liberal general incorporation acts in 1844,1855 , and 1856 , firms in Britain could organize freely as corporations, just as they could in the United States. However, corporate law in Britain, like that in France, granted companies a great deal of freedom to structure their governance rules to meet the needs of their members. British company law included a model set of governance rules that was similar to the American standard of one-vote-per-share majority rule. But the law permitted businesses to deviate from this model by writing alternative provisions into their articles of association. Further, in 1907 (even earlier than in France), Parliament passed a statute permitting firms to organize as limited liability companies similar to the German GmbH (Gower 1953 and 1956). 
This brief comparison adds support to the argument we have developed in this article: that the common-law did not evolve flexibly in accordance with businesses' needs, and that such changes as occurred over time in the menu of organizational forms and in the degree of contractual freedom available to businesses owed mainly to the passage of new statutes. It also suggests that the pace and form of these statutory changes did not correspond in any readily apparent fashion with the type of legal regime in effect in the country. Britain, like the U.S., was a common-law country, yet where organizational choices were governed by statute, British practice looked more like that of France than the U.S.

How then can we understand the recent spate of cross-country regressions that associate the French legal regime with poor economic performance? There are several possibilities. One is that the significance of the variable for legal regime is a statistical artifact that might disappear (or even reverse sign) when the model is properly specified and omitted variables are included (Acemoglu, Johnson, and Robinson 2001; Beck, Demirgüç-Kunt, and Levine 2003). A second is that the French legal system may have functioned very differently in core countries like France than in nations on the economic periphery (Beck, Demirgüç-Kunt, and Levine 2002; Berkowitz, Pistor, and Richard 2003). Yet a third possibility is that the greater contractual freedom that businesses exercised under the French code was somehow a bad thing for economic development, perhaps because it increased the uncertainty that investors or creditors faced about the nature of the businesses seeking their funds. To hold this view, however, one would have to believe that government policies that severely restricted the freedom of private parties to contract were prerequisites for economic success - a position that would seem to be directly counter to spirit that inspired this literature in the first place. 


\section{References}

Acemoglu, Daron, Simon Johnson, and James A. Robinson. "The Colonial Origins of Comparative Development: An Empirical Investigation." American Economic Review, 91 (Dec. 2001), pp. 1369-1401.

Atack, Jeremy, and Fred Bateman. "Preliminary Data on the Spread of Organizational Forms Among American Manufacturing Firms in the Nineteenth Century." Unpublished paper, 1995.

Banoff, Barbara Ann. "Company Governance Under Florida’s Limited Liability Company Act." Florida State University Law Review, 30 (Fall 2002), pp. 53-80.

Baskin, Jonathon Barron, and Paul J. Miranti, Jr. A History of Corporate Finance. New York: Cambridge University Press, 1997.

Beck, Thorsten, and Ross Levine. "Legal Institutions and Financial Development.” NBER Working Paper 10126 (2003).

Beck, Thorsten, Asli Demirgüç-Kunt, and Ross Levine. "Law and Finance: Why Does Legal Origin Matter?" Unpublished paper, 2002.

. “Law, Endowments, and Finance." Journal of Financial Economics, 69 (2003), forthcoming.

Berkowitz, Daniel, Katharina Pistor, and Jean-Francois Richard. "Economic Development, Legality and the Transplant Effect.” European Economic Review, 47 (Feb. 2003), pp. $165-95$.

Berle, Adolf A., Jr., and Gardiner C. Means. The Modern Corporation and Private Property. New York: Macmillan, 1933. 
Bishop, Carter G. "Unincorporated Limited Liability Business Organizations: Limited Liability Companies and Partnerships.” Suffolk University Law Review, 29 (Winter 1995), pp. 985-1058.

Blair, Margaret M. "Locking in Capital: What Corporate Law Achieved for Business Organizers in the $19^{\text {th }}$ Century." UCLA Law Review, 52 (2004), forthcoming.

Botero, Juan, Simeon Djankov, Rafael La Porta, Florencio Lopez-de-Silanes, and Andrei Shleifer. "The Regulation of Labor.” Unpublished paper, 2002.

Cadman, John W., Jr. The Corporation in New Jersey: Business and Politics, 1791-1875. Cambridge, Mass.: Harvard University Press, 1949.

Carlson, W. Bernard. "The Coordination of Business Organization and Technological Innovation within the Firm: A Case Study of the Thomson-Houston Electric Company in the 1880s." In Coordination and Information: Historical Perspectives on the Organization of Enterprise, ed. Naomi R. Lamoreaux and Daniel M. G. Raff. Chicago: University of Chicago Press, 1995. Pp. 55-94.

Cary, William L. "How Illinois Corporations May Enjoy Partnership Advantages: Planning for the Closely Held Firm." Northwestern University Law Review, 48 (1953), pp. 427-41.

Carney, William J. "Fundamental Corporate Changes, Minority Shareholders, and Business Purposes." American Bar Foundation Research Journal, 1980 (Winter 1980), pp. 69-132. Commercial and Financial Chronicle (1890).

Compte général de l'administration de la Justice Civile et Commerciale. Paris: imprimerie nationale, 1840-1913. 
Copper-Royer, Édouard. Traité théorique et pratique des sociétés anonymes: suivi de formules annotées concernant les actes de la vie sociale. 3 vols. $3^{\text {rd }}$ edn.; Paris: Marchal et Godde, 1925.

Dickinson, Kelvin H. "Partners in a Corporate Cloak: The Emergence and Legitimacy of the Incorporated Partnership.” American University Law Review, 33 (Spring 1984), pp. 559600.

Djankov, Simeon, Rafael La Porta, Florencio Lopez-de-Silanes, and Andrei Shleifer. "Courts." Quarterly Journal of Economics, 118 (May 2003), pp. 453-517.

Dodd, Edwin Merrick. American Business Corporations until 1860: With Special Reference to Massachusetts. Cambridge: Harvard University Press, 1954.

Dodd, E. Merrick, Jr. “Statutory Developments in Business Corporation Law, 1886-1936.” Harvard Law Review, 50 (Nov 1936), pp. 27-59.

Dunlavy, Colleen A. "From Citizens to Plutocrats: Nineteenth-Century Shareholder Voting Rights and Theories of the Corporation." In Crossing Corporate Boundaries: History, Politics, and Culture, ed. Kenneth Lipartito and David B. Sicilia. New York: Oxford University Press, forthcoming 2004.

Evans, George Heberton, Jr. Business Incorporations in the United States, 1800-1943. New York: National Bureau of Economic Research, 1948.

Forbes, Kevin F. "Limited Liability and the Development of the Business Corporation." Journal of Law, Economics, and Organization, 2 (Spring 1986), pp. 163-77.

Freedeman, Charles E. Joint-Stock Enterprise in France, 1807-1867: From Privileged Company to Modern Corporation. Chapel Hill: University of North Carolina Press, 1979. 
. The Triumph of Corporate Capitalism in France, 1867-1914. Rochester, NY:

University of Rochester Press, 1993.

Freund, Ernst. "The Legal Nature of Corporation.” Ph.D. dissertation, Columbia University, 1896.

Gazette des tribunaux: Journal de Jurisprudence et des débats judiciares. Paris: 1832-1843.

Gazur, Wayne M., and Neil M. Goff. “Assessing the Limited Liability Company.” Case Western Reserve Law Review, 41 (1991), pp. 387-501.

Gilmore, Eugene Allen. Handbook on the Law of Partnerships. St. Paul, Minn.: West Publishing, 1911.

Glaeser, Edward L., and Andrei Shleifer. "Legal Origins." Quarterly Journal of Economics, 117 (Nov. 2002), pp. 1193-229.

Glendon, Mary Ann, Michael W. Gordon, and Paolo G. Carozza. Comparative Legal Traditions in a Nutshell. $2^{\text {nd }}$ edn.; St. Paul, Minn.: West Publishing, 1999.

Gower, L. C. B. "The English Private Company." Law and Contemporary Problems, 18 (Autumn 1953), pp. 534-45.

Gower, L. C. B. "Some Contrasts Between British and American Corporation Law." Harvard Law Review, 69 (June 1956), pp. 1369-1402.

Handlin, Oscar, and Mary Flug Handlin. "Origins of the American Business Corporation." Journal of Economic History, 5 (May 1945), pp. 1-23.

Harris, Ron. Industrializing English Law: Entrepreneurship and Business Organization, 17201844. Cambridge: Cambridge University Press, 2000.

Hautcoeur, Pierre-Cyrille. "Le marché boursier et le financement des entreprises françaises, 1890-1939." Thèse de doctorat, Paris Sorbonne, 1994. 
Hawkins, David F. “The Development of Modern Financial Reporting Practices among American Manufacturing Corporations.” In Managing Big Business: Essays from the Business History Review, ed. Richard S. Tedlow and Richard R. John, Jr. Boston: Harvard Business School Press, 1986. Pp. 166-169.

Hayek, Friedrich A. The Constitution of Liberty. Chicago: University of Chicago Press, 1960. Hetherington, J.A.C., and Michael P. Dooley. "Illiquidity and Exploitation: A Proposed Statutory Solution to the Remaining Close Corporation Problem." Virginia Law Review, 63 (Feb. 1977), pp. 1-62.

Hillman, Robert W. "The Dissatisfied Participant in the Solvent Business Venture: A Consideration of the Relative Permanence of Partnerships and Close Corporations." Minnesota Law Review, 67 (Oct. 1982), pp. 1-88.

Horn, Norbert, Hein Kötz, and Hans G. Leser. German Private and Commercial Law: An Introduction, trans. Tony Weir. Oxford, Clarendon Press, 1982.

Hornstein, George D. "Stockholders' Agreements in the Closely Held Corporation.” Yale Law Journal, 59 (May 1950), pp. 1040-56.

. “Judicial Tolerance of the Incorporated Partnership." Law and Contemporary Problems, 18 (Autumn 1953), pp. 435-50.

Horwitz, Morton J. The Transformation of American Law, 1870-1960: The Crisis of Legal Orthodoxy. New York: Oxford University Press, 1992.

Houpin, C., and H. Bosvieux. Traité général, théorique et pratique des sociétés civiles et commerciales et des associations, avec formules. 2 vols. Paris: Administration du Journal des notaires et des avocats, 1935. 
Howard, Stanley E. "Business Partnerships in France Before 1807.” Accounting Review, 7 (Dec. 1932), pp. 242-57.

. "The Limited Partnership in New Jersey." Journal of Business of the University of Chicago, 7 (Oct. 1934), pp. 296-317.

Hurst, James Willard. The Legitimacy of the Business Corporation in the Law of the United States, 1780-1970. Charlottesville: University of Virginia Press, 1970.

Hurst, Thomas R. "Will the Revised Uniform Partnership Act (1994) Ever Be Uniformly Adopted?” Florida Law Review, 46 (Sept. 1996), pp. 575-89.

Kessler, William C. "Incorporation in New England: A Statistical Study, 1800-1875." Journal of Economic History, 8 (May 1948), pp. 43-62.

Kuhn, Arthur K. A Comparative Study of the Law of Corporations with Particular Reference to the Protection of Creditors and Shareholders. New York, 1912.

Lamoreaux, Naomi R. “Constructing Firms: Partnerships and Alternative Contractual Arrangements in Early-Nineteenth-Century American Business.” Business and Economic History, 24 (Winter 1995), pp. 43-71.

. "Partnerships, Corporations, and the Limits on Contractual Freedom in U.S. History: An Essay in Economics, Law, and Culture." In Crossing Corporate Boundaries: History, Politics, and Culture, ed. Kenneth Lipartito and David B. Sicilia. New York: Oxford University Press, forthcoming 2004.

La Porta, Rafael, Florencio Lopez-de-Silanes, Andrei Shleifer, and Robert W. Vishny. "Legal Determinants of External Finance.” Journal of Finance, 52 (July 1997), pp. 1131-50. . “Law and Finance.” Journal of Political Economy, 106 (Dec. 1998), pp. 1113-55. 
. "The Quality of Government," Journal of Law, Economics, and Organization, 15

(March 1999), pp. 222-79.

. “Investor Protection and Corporate Governance." Journal of Financial Economics, 58 (2000), pp. 3-27.

Lefebvre-Teillard, Anne. La société anonyme au XIXe siècle: du Code de commerce à la loi de 1867, histoire d'un instrument juridique du développement capitaliste. Paris: Presses universitaires de France, 1985.

Levine, Ross, Norman Loayza, and Thorsten Beck. "Financial Intermediation and Growth: Causality and Causes." Journal of Monetary Economics, 46 (Aug. 2000), pp. 31-77. Lewis, William Draper. “The Uniform Partnership Act—A Reply to Mr. Crane's Criticism.” Harvard Law Review, 29 (Dec. 1915), pp. 158-92.

. "The Uniform Limited Partnership Act." University of Pennsylvania Law Review, 65 (June 1917), pp. 715-31.

Livermore, Shaw. "Unlimited Liability in Early American Corporations." Journal of Political Economy, 43 (Oct. 1935), pp. 674-87.

Lyon-Cahen, Ch., and L. Renault. Manuel de droit commercial. Paris: Librairie Générale de Droit et Jurisprudence, 1924.

Mahoney, Paul G. "The Common Law and Economic Growth: Hayek Might be Right." Journal of Legal Studies, 30 (June 2001), pp. 503-25.

Maier, Pauline. "The Revolutionary Origins of the American Corporation." William and Mary Quarterly, 50 (Jan. 1993), pp. 51-84.

Martin, Joseph G. A Century of Finance: Martin's History of the Boston Stock and Money Markets. Boston, 1898 [privately printed]. 
McGuire, Patrick, Mark Granovetter, and Michael Schwartz. "Thomas Edison and the Social Construction of the Early Electricity Industry in America." In Explorations in Economic Sociology, ed. Richard Swedberg. New York: Russell Sage Foundation, 1993. Pp. 21346.

Merle, Philippe. Droit Commercial: Societés Commerciales. $6^{\text {th }}$ edn., Paris: Dalloz, 1998.

Merryman, John Henry. "The French Deviation." American Journal of Comparative Law, 44 (Winter 1996), pp. 109-19.

Mitchell, Lawrence E. “The Death of Fiduciary Duty in Close Corporations” University of Pennsylvania Law Review, 138 (June 1990), pp. 1675-31.

Moll, Douglas K. "Shareholder Oppression in Close Corporations: The Unanswered Question of Perspective." Vanderbilt Law Review, 53 (April 2000), pp. 749-827.

Navin, Thomas R., and Marian V. Sears. "The Rise of a Market for Industrial Stocks, 18871902.” Business History Review, 29 (June 1955), pp. 105-38.

North, Douglass C., and Barry R. Weingast. "Constitutions and Commitment: The Evolution of Institutions Governing Public Choice in Seventeenth-Century England.” Journal of Economic History, 49 (Dec. 1989), pp. 803-32.

O’Neal, F. Hodge. “Giving Shareholders Power to Veto Corporate Decisions: Use of Special Charter and By-Law Provisions." Law and Contemporary Problems, 18 (Autumn 1953), pp. 451-72.

O’Neal, F. Hodge. Close Corporations: Law and Practice. Chicago: Callaghan \& Co., 1958. 2 vols. . "Developments in the Regulation of the Close Corporation." Cornell Law Quarterly, 50 (Summer 1965), pp. 641-62. 
O’Neal, F. Hodge. “Close Corporations: Existing Legislation and Recommended Reform.” The Business Lawyer, 33 (Jan. 1978), pp. 873-88.

Perkins, Edwin J. American Public Finance and Financial Services, 1700-1815. Columbus: Ohio State University Press, 1994.

Plache, Lacey. "Financial Institutions, Government Policy and Industrialization: The Development of the French Stock Market, 1852-1875.” Unpublished Ph.D. dissertation, University of California, Los Angeles, 1999.

Posner, Richard A. Economic Analysis of the Law. Boston, Mass.: Little-Brown, 1973.

Pound, Roscoe. The Spirit of the Common Law. Boston, Mass.: Marshall Jones, 1921.

Priest, George L. "The Common Law Process and the Selection of Efficient Rules." Journal of Legal Studies, 6 (Jan. 1977), pp. 65-82.

Ribstein, Larry E. "Possible Futures for Unincorporated Firms." University of Cincinnati Law Review, 64 (Winter 1996), pp. 319-68.

Ripert, Georges Traité élémentaire de droit commercial. Paris : Librairie Générale de Droit et Jurisprudence, 1968.

Rivière, H. F. Répétitions écrites sur le code de Commerce. 8th edn.; Paris: A. Maresq, 1882. Rock, Edward B., and Michael L. Wachter. "Waiting for the Omelet to Set: Match-Specific Assets and Minority Oppression in Close Corporations." In Concentrated Corporate Ownership, ed. Randall K. Morck. Chicago: University of Chicago Press, 2000. Pp. 20142.

Rubin, Paul H. "Why is the Common Law Efficient?” Journal of Legal Studies, 6 (Jan. 1977), pp. 51-63. 
Rutledge, Wiley B., Jr. “Significant Trends in Modern Incorporation Statutes.” Washington University Law Review, 22 (April 1937), pp. 305-43.

Schwartz, Edward R. "The Limited Partnership Association-An Alternative to the Corporation for the Small Business with 'Control' Problems?” Rutgers Law Review, 20 (1965), pp. $29-88$.

Stone, Harlan F. "The Common Law in the United States." Harvard Law Review, 50 (Nov. 1936), pp. 4-26.

Story, Joseph. Commentaries on the Law of Partnership, as a Branch of Commercial and Maritime Jurisprudence with Occasional Illustrations from the Civil and Foreign Law. $5^{\text {th }}$ edn.; Boston: Little, Brown, 1859.

Stover, Fallany O., and Susan Pace Hamill. "The LLC Versus LLP Conundrum: Advice for Businesses Contemplating the Choice.” Alabama Law Review, 50 (Spring 1999), pp. 813-47.

U.S., Census Office. Twelfth Census: Manufacturers. Washington, DC: U.S. Census Office, 1902, Vol. 7.

U.S., Internal Revenue Service. Statistics of Income-1920. Washington, DC: Government Printing Office, 1922.

U.S., Internal Revenue Service, Statistics of Income-1976: Business Income Tax Return. Washington, DC: Government Printing Office, 1979.

Warren, Edward H. Corporate Advantages without Incorporation. New York: Baker, Voorhis \& Co., 1929.

Watson, Alan., Legal Transplants: An Approach to Comparative Law. Edinburgh, Scottish Academic Press, 1974. 
Weber, Max. On Law in Economy and Society, ed. Max Rheinstein and trans. Edward Shils and Rheinstein. Trans. of 1925 edn; Cambridge: Harvard University Press, 1954.

Woodward, Susan E. "Limited Liability in the Theory of the Firm." Journal of Institutional and Theoretical Economics, 141 (Dec. 1985), pp. 601-11.

Zwiegart, Konrad, and Hein Kötz. Introduction to Comparative Law, trans. Tony Weir. $3^{\text {rd }}$ edn., rev.; Oxford: Oxford University Press, 1998. 
Table 1

Availability of the Basic Forms of Organization in the United States and France

\begin{tabular}{|l|l|l|l|}
\hline \multirow{2}{*}{ Type of form } & Definition of form & \multicolumn{2}{|c|}{ Available in } \\
\hline $\begin{array}{l}\text { Ordinary partnership } \\
\text { (société en nom } \\
\text { collectif) }\end{array}$ & $\begin{array}{l}\text { Two or more partners, all } \\
\text { unlimitedly liable }\end{array}$ & Yes & Yes \\
\hline $\begin{array}{l}\text { Limited partnership } \\
\text { (commandite simple) }\end{array}$ & $\begin{array}{l}\text { One or more general partners with } \\
\text { unlimited liability and one or more } \\
\text { special partners who cannot } \\
\text { participate in management but who } \\
\text { have limited liability }\end{array}$ & $\begin{array}{l}\text { Yes, but } \\
\text { provisions } \\
\text { less } \\
\text { attractive }\end{array}$ & Yes \\
\hline $\begin{array}{l}\text { Limited partnership with } \\
\text { shares (commandite par } \\
\text { action) }\end{array}$ & $\begin{array}{l}\text { Same as above, except special } \\
\text { partners' shares can be bought and } \\
\text { sold }\end{array}$ & No & Yes \\
\hline $\begin{array}{l}\text { Limited liability } \\
\text { company (société à } \\
\text { responsabilité limitée) }\end{array}$ & $\begin{array}{l}\text { All members have limited liability, } \\
\text { but their shares are not tradable }\end{array}$ & $\begin{array}{l}\text { Not until the } \\
\text { late 1980s }\end{array}$ & $\begin{array}{l}\text { After } \\
1925\end{array}$ \\
\hline $\begin{array}{l}\text { Corporation (société } \\
\text { anonyme) }\end{array}$ & $\begin{array}{l}\text { All members have unlimited } \\
\text { liability and their shares are tradable }\end{array}$ & $\begin{array}{l}\text { Yes after } \\
\text { c1850, } \\
\text { increasingly } \\
\text { before then }\end{array}$ & $\begin{array}{l}\text { Yes } \\
\text { after } \\
1867 \\
\text { limited } \\
\text { before } \\
\text { then }\end{array}$ \\
\hline
\end{tabular}


Table 2

Restrictions on the Activities of Members of Ordinary Partnerships

\begin{tabular}{|c|c|c|c|c|c|}
\hline $\begin{array}{c}\text { Number of } \\
\text { Partners }\end{array}$ & $\begin{array}{c}\text { Firm } \\
\text { Cannot } \\
\text { Borrow }\end{array}$ & $\begin{array}{c}\text { Joint } \\
\text { Signature } \\
\text { Required to } \\
\text { Encumber } \\
\text { the Firm } \\
\end{array}$ & $\begin{array}{c}\text { Delegated } \\
\text { Management }\end{array}$ & $\begin{array}{l}\text { Partnerships } \\
\text { Without } \\
\text { Restrictions }\end{array}$ & Total \\
\hline & \multicolumn{5}{|c|}{ Number of Firms } \\
\hline 2 & 238 & 905 & 755 & 1847 & 3617 \\
\hline 3 & 61 & 180 & 305 & 228 & 685 \\
\hline 4 & 31 & 31 & 104 & 42 & 168 \\
\hline$>4$ & 18 & 20 & 65 & 6 & 73 \\
\hline \multirow[t]{2}{*}{ Total } & 277 & 982 & 971 & 1872 & 3879 \\
\hline & \multicolumn{5}{|c|}{ Percentage of Row Total } \\
\hline 2 & 6.6 & 25.0 & 20.9 & 51.1 & \\
\hline 3 & 8.9 & 26.3 & 44.5 & 33.3 & \\
\hline 4 & 18.5 & 18.5 & 61.9 & 25.0 & \\
\hline$>4$ & 22.8 & 25.3 & 82.3 & 7.6 & \\
\hline Total & 7.7 & 25.0 & 27.0 & 46.7 & \\
\hline
\end{tabular}

Source: Notices of new firms published in the Gazette des tribunaux from 1 January 1832 through 31 December 1843.

Note: "Cannot borrow" refers to partnership contracts that required all business to be on a cash basis. "Joint signature" contracts required more than one partner (though not necessarily all) to sign any debt instrument. "Delegated management" contracts gave a subset of partners the right to manage the firm on a day-to-day basis and could occur with either (or none) of the previous clauses. "Without restrictions" means that each partner had full ownership rights. 
Table 3

Restrictions on the Activities of General Partners in Commandites Simples

\begin{tabular}{|c|c|c|c|c|c|}
\hline $\begin{array}{l}\text { Number of } \\
\text { General } \\
\text { Partners }\end{array}$ & $\begin{array}{c}\text { Firm } \\
\text { Cannot } \\
\text { Borrow }\end{array}$ & $\begin{array}{c}\text { Joint } \\
\text { Signature } \\
\text { Required to } \\
\text { Encumber } \\
\text { the Firm }\end{array}$ & $\begin{array}{c}\text { Delegated } \\
\text { Management }\end{array}$ & $\begin{array}{c}\text { Partnerships } \\
\text { Without } \\
\text { Restrictions }\end{array}$ & Total \\
\hline & \multicolumn{5}{|c|}{ Number of Firms } \\
\hline 1 & 113 & -- & -- & 642 & 755 \\
\hline 2 & 37 & 38 & 72 & 213 & 347 \\
\hline 3 & 5 & 9 & 16 & 25 & 50 \\
\hline$>3$ & 3 & 2 & 10 & 3 & 15 \\
\hline \multirow[t]{5}{*}{ Total } & 158 & 49 & 98 & 806 & 1081 \\
\hline & \multicolumn{5}{|c|}{ Percentage of Row Total-All Firms } \\
\hline & 13.0 & 4.7 & 8.4 & 76.0 & \\
\hline & \multicolumn{5}{|c|}{ Percentage of Row Total_Firms With More Than One General Partner } \\
\hline & 10.1 & 11.8 & 23.7 & 58.3 & \\
\hline
\end{tabular}

Sources and Notes: See Table 2. 
Table 4

Restrictions on the Activities of General Partners in Commandites par Action

\begin{tabular}{|c|c|c|c|c|c|}
\hline $\begin{array}{c}\text { Number of } \\
\text { General } \\
\text { Partners } \\
\end{array}$ & $\begin{array}{c}\text { Firm } \\
\text { Cannot } \\
\text { Borrow }\end{array}$ & $\begin{array}{c}\text { Joint } \\
\text { Signature } \\
\text { Required to } \\
\text { Encumber } \\
\text { the Firm } \\
\end{array}$ & $\begin{array}{c}\text { Delegated } \\
\text { Management }\end{array}$ & $\begin{array}{c}\text { Partnerships } \\
\text { Without } \\
\text { Restrictions }\end{array}$ & Total \\
\hline & \multicolumn{5}{|c|}{ Number of Firms } \\
\hline 1 & 262 & 9 & -- & 869 & 1142 \\
\hline 2 & 87 & 48 & 117 & 204 & 429 \\
\hline$>2$ & 42 & 41 & 85 & 48 & 170 \\
\hline \multirow[t]{5}{*}{ Total } & 391 & 98 & 203 & 1121 & 1740 \\
\hline & \multicolumn{5}{|c|}{ Percentage of Row Total-All Firms } \\
\hline & 22.5 & 5.6 & 11.6 & 64.4 & \\
\hline & \multicolumn{5}{|c|}{ Percentage of Row Total_Firms With More Than One General Partner } \\
\hline & 21.5 & 14.9 & 33.7 & 42.1 & \\
\hline
\end{tabular}

Sources and Notes: See Table 2. 


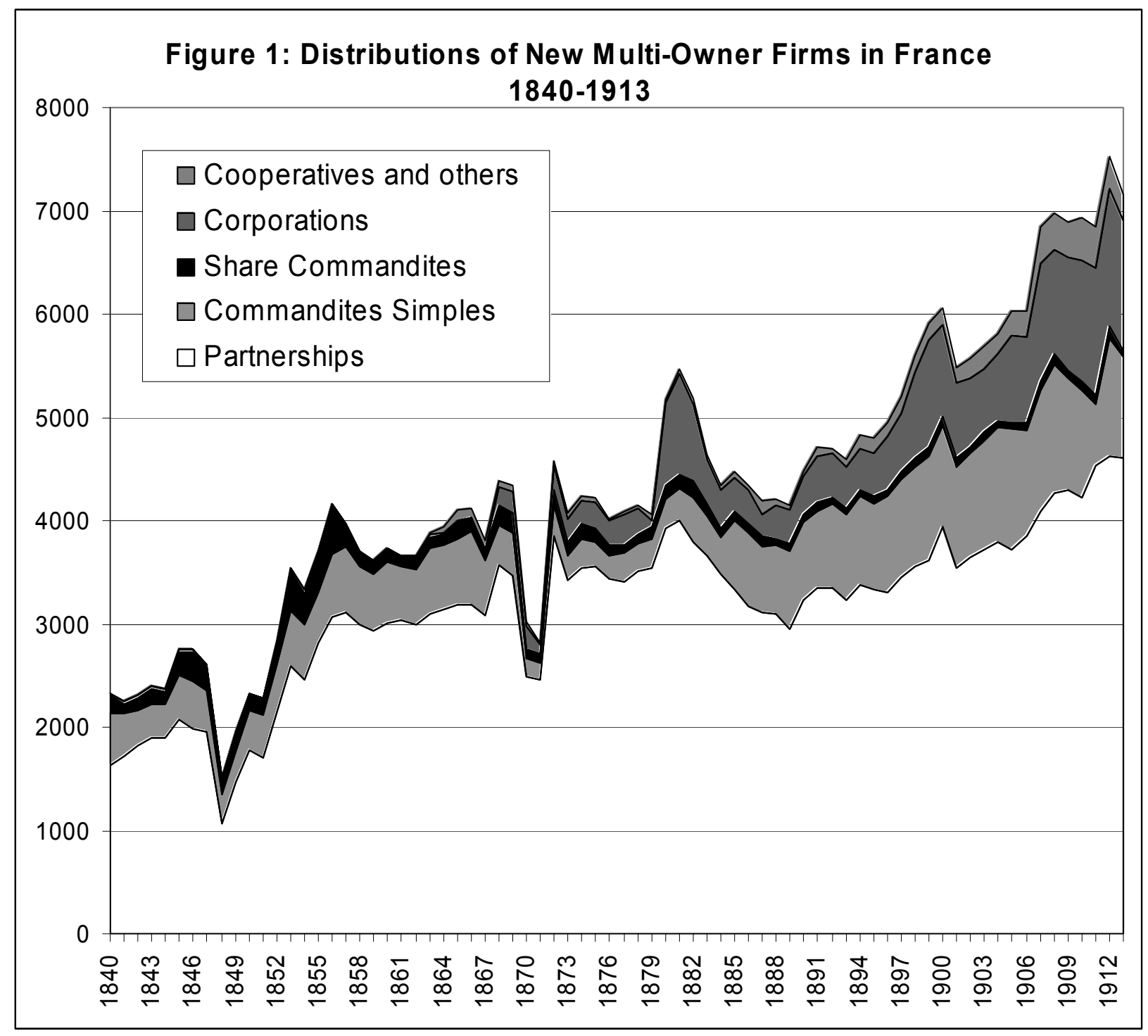

Source: Annual issues of the Compte général de l'administration de la justice civile et commerciale. 


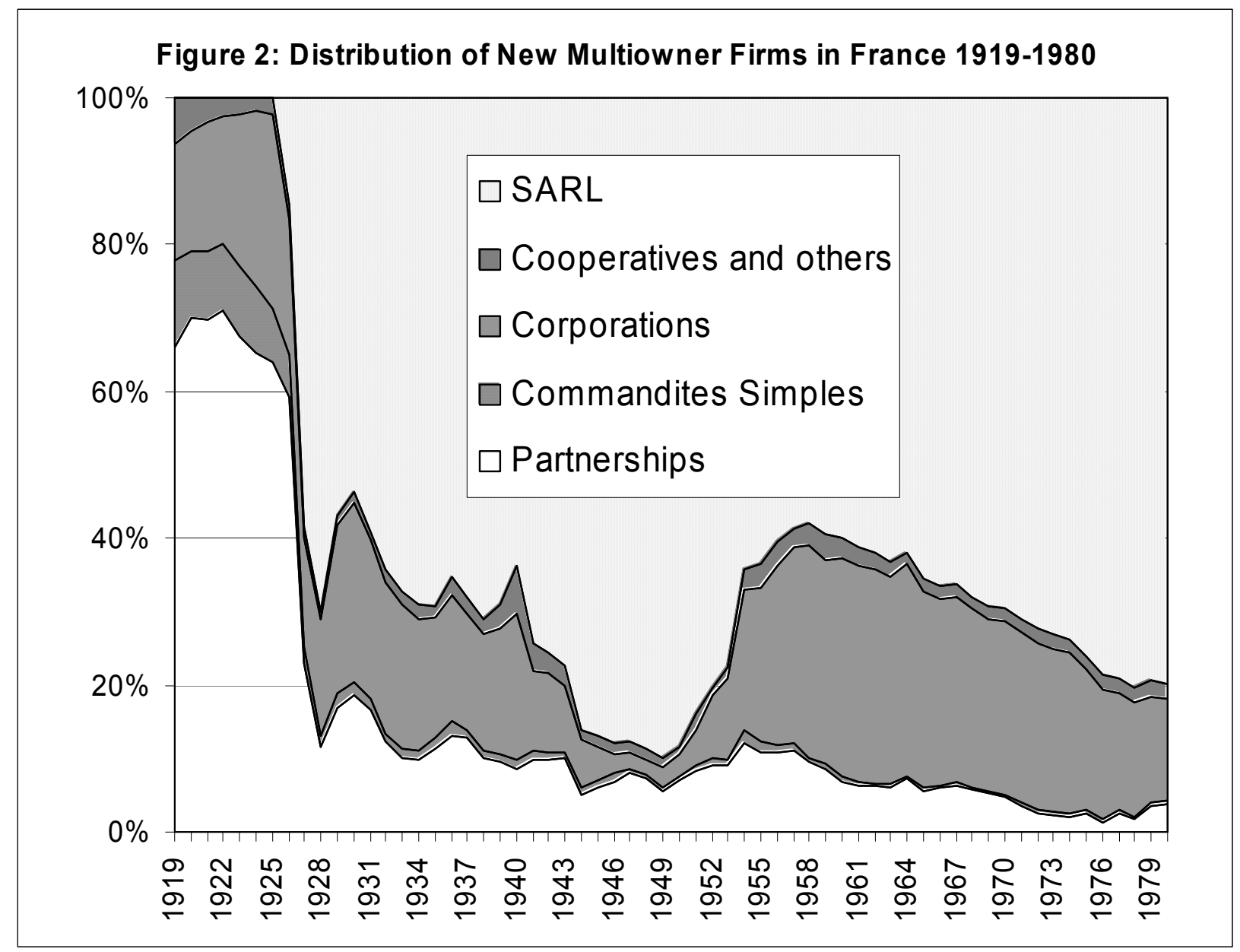

Source: Annual issues of the Compte général de l'administration de la justice civile et commerciale. 